\title{
COMPARATIVE ULTRASTRUCTURAL AND HISTOCHEMICAL STUDIES OF THE INTERSTITIAL CELLS OF THE RAT TESTIS DURING FETAL AND POSTNATAL DEVELOPMENT
}

\author{
D. W. LORDING AND D. M. DE KRETSER \\ Departments of Anatomy and Medicine, Monash University, \\ Melbourne, Victoria 3168, Australia
}

(Received 27th April 1971, accepted 7th July 1971)

\begin{abstract}
Summary. The interstitial cells of the albino rat testis were studied in animals ranging from the 15th day of fetal life until adulthood. The interstitial cells developed in two phases, a fetal phase from the 17th fetal day to the 2nd postnatal week and an adult phase from the 3rd week onwards. Lipid histochemical and ultrastructural techniques demonstrated the abundance of lipid droplets in the fetal interstitial cells and the paucity of lipid in the adult interstitial cells. The enzyme $\Delta_{5}-3 \beta$-hydroxysteroid dehydrogenase (HSD) was studied in the interstitial cells throughout development using dehydroepiandrosterone (DHEA), pregnenolone and $17 \alpha$-hydroxy pregnenolone as substrates. The enzyme activity was found with all substrates in both types of interstitial cells, DHEA producing the greatest reaction. The activity of HSD using pregnenolone on substrates was greater in the fetal interstitial cells.

The ultrastructural studies demonstrated the presence of abundant agranular endoplasmic reticulum in both the fetal and adult interstitial cells. The prominent cup-shaped mitochondria and lipid droplets present in the fetal cells were not present in the adult interstitial cells. The differences in the histochemical and ultrastructural features of the cells of each phase suggests that they represent separate generations of interstitial cells.
\end{abstract}

\section{INTRODUCTION}

The studies of Roosen-Runge \& Anderson (1959) have demonstrated that the interstitial cells of the rat testis undergo two marked growth phases. These were termed the 'fetal' and 'adult' generations. However, it is not clear whether these two growth phases represent two disinct generations of interstitial cells as described by Mancini, Vilar, Lavieri, Andrada \& Heinrich (1963) in their study of the developing human testis.

Studies on the interstitial cells of the adult rat testis have included investigations of their fine structure (Leeson, 1963; Schwarz \& Merker, 1965; Murakami, 1966) and the histochemical distribution of $\Delta_{5}-3 \beta$-hydroxysteroid 
dehydrogenase (Wattenberg, 1958; Levy, Deane \& Rubin, 1959). Reports of similar detailed studies on the fetal testicular interstitial cells in the rat are not available.

The ultrastructural studies of Christensen (1959) and Christensen \& Chapman (1959) commented on minor changes in the interstitial cells of the rat testis during development. Baillie \& Griffiths (1964a, b) from their histochemical studies of $\Delta_{5}-3 \beta$-hydroxysteroid dehydrogenase (HSD) demonstrated a variation in substrate specificity during development of the interstitial cells of the mouse testis.

In this report, the results of detailed ultrastructural and histochemical studies of the rat testis throughout development are presented. Several important differences between the two generations of interstitial cells were observed and are described in this paper.

\section{MATERIALS AND METHODS}

Small pieces of testis from twenty-seven different groups of rats between the ages of the 15th fetal day and adulthood (100 days) were prepared for ultrastructural investigations and for histochemical study of lipid and the enzyme HSD. All animals were killed by cervical dislocation or decapitation and the tissues were removed immediately and appropriately prepared.

\section{Light microscopy}

The tissue was immersed in Bouin's fixative for $24 \mathrm{hr}$, then dehydrated in alcohol and embedded in paraffin wax. Sections cut at $5 \mu \mathrm{m}$ were mounted and stained with haematoxylin and eosin.

\section{Histochemical demonstration of $\Delta_{5}-3 \beta$-hydroxysteroid dehydrogenase}

Frozen sections, approximately $14 \mu \mathrm{m}$ thick, were treated in the manner previously described (Baillie, Ferguson \& Hart, 1966) for the demonstration of HSD. Eight sections of each specimen were incubated with four different media, three of which contained a steroid substrate with a $3 \beta$-hydroxyl configuration and the other served as a control without substrate. The substrates used were dehydroepiandrosterone (DHEA), pregnenolone and $17 \alpha$-hydroxypregnenolone (Sigma Chemical Co.).

The sections were incubated for $90 \mathrm{~min}$ at $37^{\circ} \mathrm{C}$, washed in Sorensen's phosphate buffer and fixed in $10 \%$ neutral formalin for $10 \mathrm{~min}$. After mounting on slides using the aqueous mountant, Hydramount, the sections were examined by light microscopy.

\section{Histochemical demonstration of lipid}

The tissues were fixed in $10 \%$ formol calcium and subsequently, having been washed for $72 \mathrm{hr}$ in running water, were embedded in $12 \%$ gelatin. Cryostat sections (6 to $10 \mu \mathrm{m}$ ) were mounted on slides and dehydrated in propylene glycol. The sections were stained with Sudan Black or Fettrot by a modification of the method of Chiffelle \& Putt (1951) as described by Pearse (1961). Following rinsing and differentiation in propylene glycol, the sections were washed in 
warm running tap-water, counterstained with haematoxylin and eosin and overlaid with coverslips using Apathy's gummy syrup.

In addition, $1-\mu \mathrm{m}$ sections of araldite-embedded material fixed in osmium tetroxide were stained with toluidine blue.

\section{Electron microscopy}

Small pieces of testis were immediately placed in cold $2.5 \%$ osmium tetroxide buffered with a potassium dichromate-calcium chloride mixture (Richardson, 1962 ) for $2 \mathrm{hr}$. In addition, some tissue was fixed initially in $5 \%$ phosphatebuffered glutaraldehyde for $2 \mathrm{hr}$ followed by post-fixation in $2.5 \%$ osmium tetroxide for $1 \mathrm{hr}$. After washing in distilled water, the specimens were dehydrated in graded concentrations of acetone and embedded in Araldite. Thin sections, exhibiting silver to gold interference colours were stained with aqueous uranyl acetate (Watson, 1958) followed by lead citrate (Reynolds, 1963). The sections were then examined in a Siemens Elmiskop IA at $80 \mathrm{kV}$.

\section{Statistical analysis}

Sections prepared for light microscopy and steroid histochemistry were subjected to quantitative analysis. A grid in the eyepiece of the microscope outlined a field of $24,000 \mu \mathrm{m}^{2}$ and the number of mature interstitial cells in twenty such fields was determined, thereby establishing the number of mature interstitial cells in an area of $480,000 \mu \mathrm{m}^{2}$. The calculations were performed using five samples of each specimen from twelve different age groups in the developmental series from the 18th day of fetal life until 10 weeks after birth. The mean and standard deviation of these estimates for each age group were then calculated.

In addition, the proportion of an area of $1,600,000 \mu \mathrm{m}^{2}$ which exhibited a positive steroid histochemical reaction with DHEA was measured. The grid which outlined an area of $160,000 \mu \mathrm{m}^{2}$ was divided into 100 squares. The number of squares occupied by formazan deposits was calculated in an area outlined by ten of these grids. Five specimens from each of twelve different age groups were assessed and the results analysed by the same procedure as that used in the analysis of the number of interstitial cells.

\section{OBSERVATIONS}

\section{Light microscopy}

The mature interstitial or Leydig cells were easily identified in the intertubular area by their abundant eosinophilic cytoplasm and large oval nuclei which contained prominent nucleoli. Total cell counts of the number of mature interstitial cells in the testis at different ages (Text-fig. 1) indicate that they were most prominent in the fetal and pubertal testis and were present in minimum numbers during the 2 nd postnatal week.

\section{Steroid histochemistry}

In the testes of rats, from the 15th day of fetal life to adulthood, formazan deposits representing HSD activity were present after incubation in all three 
media containing a steroid substrate. The reactive areas were found exclusively in the interstices between the seminiferous tubules or between the tunica albuginea and the surrounding tubules (Pl. 1, Figs. 3 and 4). Formazan deposits were absent after incubation in control media which did not contain a steroid substrate.

The distribution of the formazan deposits in the testes at all the ages studied corresponded with the distribution of interstitial cells. The proportion of a fixed area of the testis occupied by formazan deposits was maximal in the fetal and pubertal testis and minimal during the 2nd postnatal week (Text-fig. 2).

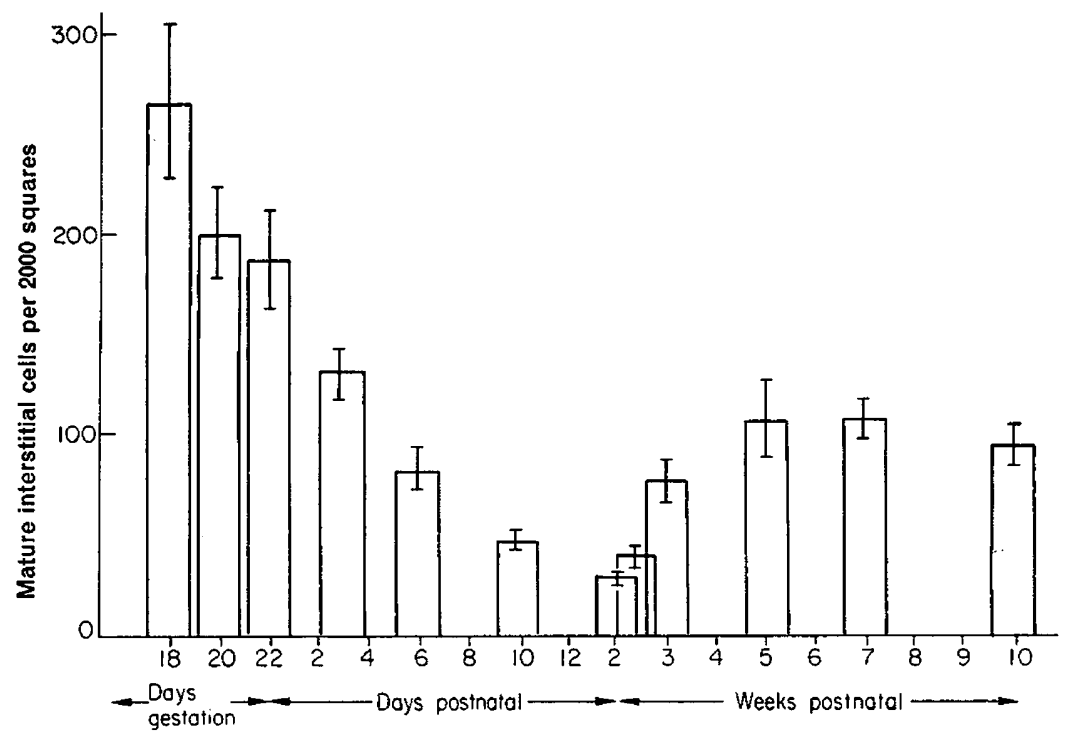

TEXT-FIG. 1. The variation of the number of mature interstitial cells in a fixed area $\left(480,000 \mu \mathrm{m}^{2}\right)$ of the developing rat testis (mean and standard deviation plotted).

This pattern did not alter with the steroid substrate used although variations in the intensity of the reaction were observed using different steroid substrates at various stages of testicular development.

With the DHEA as substrate, the intensity of the formazan deposits was always as great as, or greater than, the intensity of the reaction using any of the other steroid substrates. The intensity increased to a maximal level

\section{EXPLANATION OF PLATE 1}

Fig. 1. Illustrates the presence of large numbers of lipid droplets $(\Delta)$ in the interstitial cells of a 19-day fetal rat testis. The seminiferous cords $(T)$ are also shown. Osmium-fixed, Araldite-embedded, toluidine blue stain. $\times 500$.

Fig. 2. The interstitial cells ( $\Lambda$ ) of the adult rat testis are shown and lack the collections of lipid seen in the fetal cells. Osmium-fixed, Araldite-embedded, toluidine blue stain. $\times 500$.

FIG. 3. The typical histochemical activity of $3 \beta$-hydroxysteroid dehydrogenase in the fetal interstitial cells is illustrated using (a) $17 \alpha$-hydroxy pregnenolone, (b) dehydroepiandrosterone, (c) control, (d) pregnenolone. $\times 100$.

Frg. 4. The typical histochemical activity of $3 \beta$-hydroxysteroid dehydrogenase of the adult generation of interstitial cells is shown using (a) $17 \alpha$-hydroxypregnenolone, (b) dehydroepiandrosterone, (c) control, (d) pregnenolone. $\times 100$. 
PL.ATE I
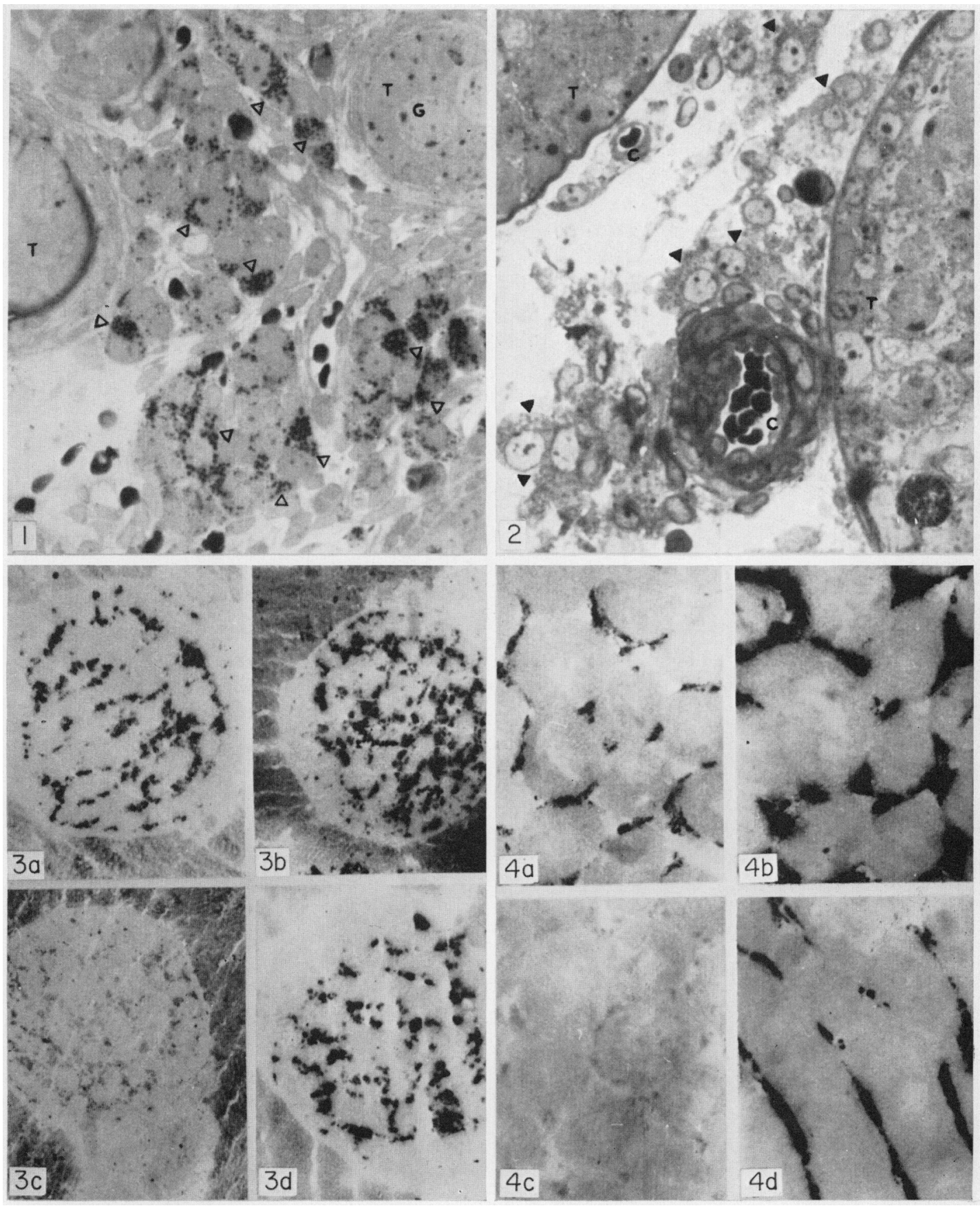

(Facing p. 264) 


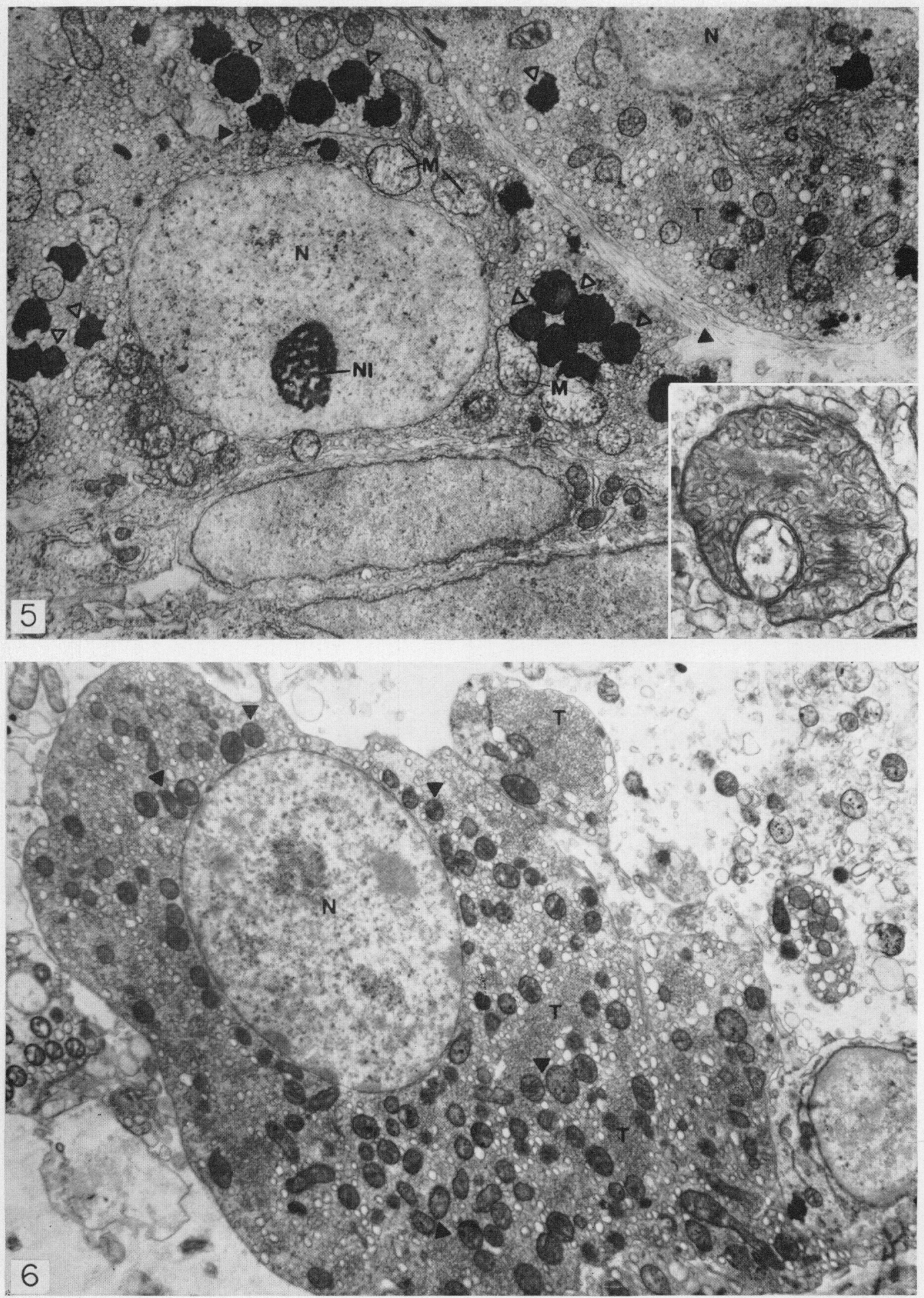


from the 14th to the 17th fetal day and remained at this level throughout subsequent testicular development despite variations in the relative size of the reactive areas. With pregnenolone, the intensity of the deposits was less than those with DHEA from the 14th to 18th fetal days. During subsequent fetal development, the intensity with both substrates was equivalent and remained so until the 2nd postnatal week when there was a reduction in the intensity of the formazan deposits using pregnenolone as substrate. With $17 \alpha$-hydroxypregnenolone as substrate, the intensity of the formazan deposits in the in-

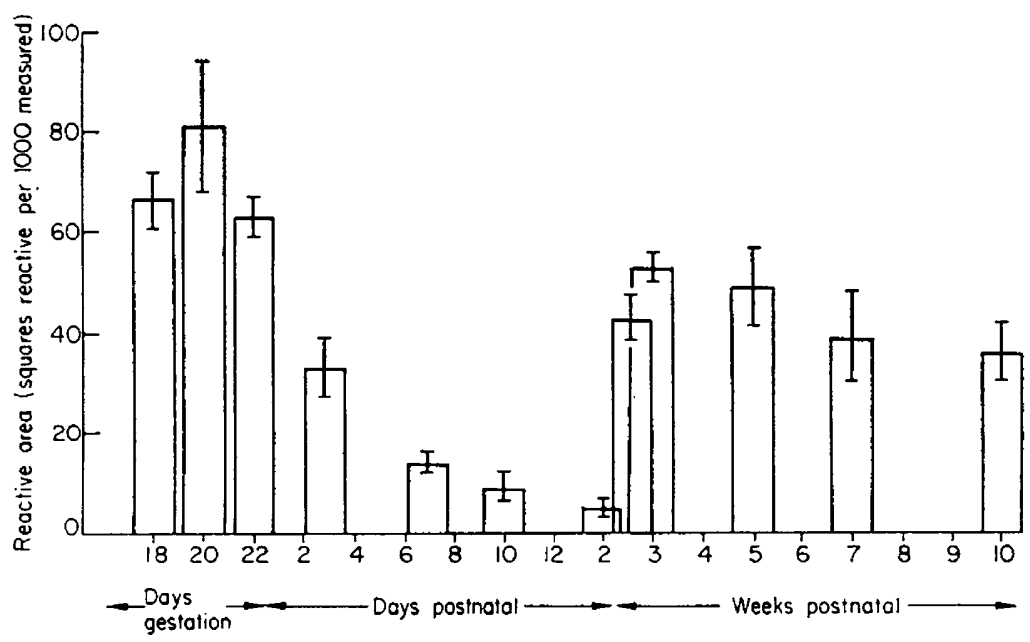

Text-rig. 2. The variation of the number of areas in the developing rat testis exhibiting positive $3 \beta$-hydroxysteroid dehydrogenase reactivity (mean and standard deviation plotted).

tertubular areas was minimal at all ages studied throughout the development of the rat testis.

\section{Lipid histochemistry}

Using the Fettrot and Sudan Black techniques, abundant lipid was demonstrated in the cytoplasm of fetal testicular interstitial cells. After birth, the amount of demonstrable lipid present decreased and disappeared from interstitial cells during the 2nd postnatal week. The interstitial cells of the testis at later stages of development contained no demonstrable lipid. These observations were confirmed by studies of toluidine-blue-stained sections of

\section{EXPLANATION OF PLATE 2}

Fig. 5. This electronmicrograph illustrates a group of interstitial cells from a 20-day old fetal rat testis and demonstrates the nucleus $(\mathrm{N})$, nucleolus $(\mathrm{Nl})$, mitochondria $(\mathrm{M})$, Golgi complex (G) and lipid inclusions $(\Delta)$. The agranular endoplasmic reticulum is present as many vesicles and small groups of tubules (T). The surrounding collagen fibres (A) can be seen $\times 6900$. Inset shows a typical mitochondrion from these cells.

Fig. 6. An interstitial cell from the adult rat testis is shown with nucleus (N) and mitochondria ( $\Delta$ ). The agranular endoplasmic reticulum is composed of vesicles of variable diameter and collections of small interconnected tubules $(T) . \times 4800$. 
Araldite-embedded testicular material in which lipid droplets appeared as inclusions staining bluish-black in colour (Pl. 1, Figs. 1 and 2).

\section{Ultrastructural studies}

The mature interstitial cells of the fetal and pubertal rat testis were characterized by a large round or oval nucleus and abundant cytoplasm containing numerous organelles. Included in these were abundant agranular endoplasmic reticulum, scattered elements of granular endoplasmic reticulum, a small but prominent Golgi apparatus and numerous mitochondria (Pl. 2, Figs. 5 and 6). The form of the mitochondria was different in the typical interstitial cell of each generation and, in addition, abundant osmophilic lipid droplets were seen only in the interstitial cells of the fetal generation.

In the fetal interstitial cells (P1. 2, Fig. 5), the agranular endoplasmic reticulum took the form of vesicles of variable diameter and small collections of tubules in specimens fixed with osmium tetroxide. In glutaraldehyde-fixed tissue, the agranular endoplasmic reticulum of the fetal interstitial cells was present as a system of interconnected tubules. In many areas of the adult interstitial cells, the agranular endoplasmic reticulum was present as a system of vesicles but, in other regions, large collections of densely packed tubules were observed in the same cell (Pl. 2, Fig. 6). The arrangement was present in specimens fixed either by glutaraldehyde or osmium tetroxide.

Numerous large mitochondria were present in the cytoplasm of fetal interstitial cells and they varied markedly in shape and size. Round, elongated and annular mitochondrial profiles were frequently observed and many of these profiles represent sections of cup-shaped mitochondria (Pl. 2, Fig. 5). In the interstitial cells of the adult generation, the mitochondria were more regular in size and shape and contained small, dark intramitochondrial inclusions not present in those of the fetal generation. Cup-shaped mitochondria were not observed in the adult interstitial cell. In both fetal and adult generations of interstitial cells, the mitochondria contained numerous cristae, the majority of which were tubular in cross section.

\section{DISCUSSION}

The results of this study demonstrate the presence of two growth phases of interstitial cells during development of the rat testis. The results strongly suggest the presence of two distinct generations of interstitial cells but the evidence is not conclusive due to the overlap of the two generations during the 2nd and 3rd postnatal weeks. The variation in the histochemistry and ultrastructure that have been demonstrated during development add important information relating to the growth phases of the cells.

The limitations of the histochemical method used for demonstrating HSD have been discussed by Baillie et al. (1966) and Woods \& Domm (1966). It is sufficient to state in this paper that all observations of change in the intensity of the formazan deposits used to demonstrate HSD activity must be interpreted with care.

It seems probable that the change in intensity of the histochemical reaction 
in the interstitial cells, using pregnenolone as substrate, which occurred during the 2nd postnatal week, may represent a change in substrate specificity of HSD. Alternatively, the results may indicate that developmental changes occur in the system proposed by Taladay (1957) where each steroid substrate with $3 \beta$ hydroxyl radical has its own dehydrogenase enzyme. Despite the uncertainty in the interpretation, it is clear that some change in the steroid biosynthetic pathways within interstitial cells takes place during this period. This postulate is supported by the results of biochemical studies by Steinberger \& Ficher (1968).

The results of the present study clearly indicate that the amount of demonstrable lipid varies between the two growth phases of the interstitial cells. The demonstrable lipid is abundant in the fetal growth phase but is virtually absent in the adult growth phase. The use of histochemistry, toluidine-blue-stained sections of Araldite-embedded material and electron microscopy all demonstrate the difference in the number of lipid droplets found in the interstitial cells of the two growth phases. The absence of lipid in the adult generation of interstitial cells is supported by the results obtained by Niemi \& Ikonen (1963).

The interpretation of the difference in the lipid content of the interstitial cells is difficult but in the context of the results of the histochemical and ultrastructural components of the present study, the findings strongly suggest the presence of two separate generations of interstitial cells. The change in the amount of demonstrable lipid which occurs after birth parallels the termination of the first growth phase of interstitial cells. If this lipid is in some way related to interstitial cell secretion, then these results would suggest that there is a different mechanism of secretion in the fetal and adult interstitial cells. Alternatively, the lipid inclusions may represent storage of a steroid precursor, perhaps resulting from immaturity of the enzyme systems involved in their metabolism.

The characteristic organelles of the fetal and adult rat interstitial cells observed in this study are abundant agranular endoplasmic reticulum and numerous mitochondria with tubular cristae. These features have been shown to be characteristic of the steroid producing cells of the adrenal cortex, the ovary (Brenner, 1966; Blanchette, 1966) and the adult rat testis (Leeson, 1963). The steroid biosynthetic function of the adult, interstitial cell is beyond doubt (Christensen \& Mason, 1965; Hall, Irby \& de Kretser, 1969). Evidence is accumulating which clearly indicates that the fetal interstitial cell secretes androgens (Noumura, Weisz \& Lloyd, 1966), and the ultrastructural features demonstrated in the present study add support to this proposal.

The most obvious of the features distinguishing the fetal and adult interstitial cell is the presence of large, intensely osmophilic lipid droplets in the fetal cell and the paucity of such droplets in the adult interstitial cell. Previous ultrastructural studies of the rat testis (Leeson, 1963; Schwarz \& Merker, 1965), have shown that lipid droplets are an inconstant feature of adult interstitial cells. The ultrastructural observations presented in this study are supported by the results of the histochemical study of lipid in these cells.

Similarly, minor differences were found in the typical mitochondria of each generation. Since mitochondria are involved in the cleavage of the side chain of cholesterol (Toren, Menon, Forchielli \& Dorfman, 1964), the observations of differences in mitochondrial structure in the cells of the two growth phases is in 
keeping with the postulate that the fetal and adult interstitial cells may be in different functional states. Evidence that the pattern of steroid production can change during testicular development in the rat was presented recently by Steinberger \& Ficher (1968). Their results further support the presence of two generations of interstitial cells with different metabolic pathways.

On the basis of these differences between the interstitial cells of the fetal and adult growth phases, it is proposed that the cells represent two distinct populations. Unlike the two easily separable generations of interstitial cells found in the human testis (Mancini et al., 1963), some overlap occurs between the two interstitial populations in the rat. The difference in the developmental sequence of interstitial cell growth exhibited by the human and rat testis may be related to the fact that the time from birth to puberty in the two species varied greatly. In the rat, this period is about 7 weeks, which is about $\frac{1}{20}$ of the total life-span. Assuming that two generations of interstitial cells occur, the time between the stimulus for the involution of the fetal generation and the stimulus for initiation of the adult generation varies greatly in the two species. Hence, it is possible that, although two generations may occur in the rat, the time interval between each may be insufficient to allow total degeneration of the first before the appearance of the second generation.

\section{ACKNOWLEDGMENTS}

The assistance of Miss S. Ebbott, Mrs W. Rodell, Mr T. Mecziems and Mr J. Simmons during this study is gratefully acknowledged. The authors wish to thank Professor G. C. Schofield for his helpful advice during this study. This study was supported by grants from the National Health and Medical Research Council of Australia.

\section{REFERENCES}

Baillie, A. H., Ferguson, M. D. \& Hart, D. McK. (1966) Developments in steroid histochemistry. Academic Press, London.

Baillie, A. H. \& Grifriths, K. (1964a) $3 \beta$-Hydroxysteroid dehydrogenase activity in the mouse Leydig cell. F. Endocr. 29, 9.

Baileie, A. H. \& Griffiths, K. (1964b) $3 \beta$-Hydroxysteroid dehydrogenase in the foetal mouse Leydig cell. F. Endocr. 31, 63.

Blanchette, E. J. (1966) Ovarian steroid cells. I. Differentiation of lutein cell from granulosa follicle cell during the preovulatory stage and under the influence of exogenous gonadotropin. II. The lutein cell. F. Cell Biol. 31, 501.

BRENNER, R. M. (1966) Fine structure of adrenocortical cells in adult male Rhesus monkeys. Am. $\mathcal{F}$. Anat. 119, 429.

Chiffelle, T. L. \& Putr, F. A. (1951) Propylene and ethylene glycol as solvents for Sudan IV and Sudan Black B. Stain Tech. 26, 51.

Christensen, A. K. (1959) The fine structure of interstitial tissue of the rat testis of various ages and after experimental treatment. (Abstract). Anat. Rec. 133, 367,

Christensen, A. K. \& Chapman, G. B. (1959) Cup-shaped mitochondria in interstitial cells of the albino rat testis. Expl Cell Res. 18, 576.

Christensen, A. K. \& Mason, N. R. (1965) Comparative ability of seminiferous tubules and interstitial tissue of rat testes to synthesize androgens from progesterone- $4-{ }^{14} \mathrm{C}$ in vitro. Endocrinology, 76,646 .

HALI, P. F., IRby, D. C. \& DE Kretser, D. M. (1969) Conversion of cholesterol to androgens by rat testes: comparison of interstitial cells and seminiferous tubules. Endocrinology, 84, 488.

LeEson, C. R. (1963) Observations on the fine structure of rat interstitial tissue. Acta anat. 52, 34. 
Levy, H., Deane, H. W. \& Rubin, B. L. (1959) Visualization of steroid $3 \beta$-ol-dehydrogenase activity in tissues of intact and hypophysectomized rats. Endocrinology, 65, 932.

Mancini, R. E., Vilar, O., Lavieri, J. E., Andrada, J. A. \& Heinrich, J. J. (1963) Development of Leydig cells in the normal human testis. A cytological, cytochemical and quantitative study. Am. F. Anat. 122, 203.

MuRakam, M. (1966) Electronmikroskopische Untersuchungen am Interstitiellen gewebe des Rattenhodens unter besonderer Berucksichtigung der Leydigschen Zwischenzellen. Z. Zellforsch. mikrosk. Anat. 72, 139.

NIEMI, M. \& IKoNEN, M. (1963) Histochemistry of the Leydig cells in the postnatal prepubertal testis of the rat. Endocrinology, 74, 996.

Noumara, T., WEIsz, J. \& LLOYD, C. W. (1966) In vitro conversion of $7-{ }^{3} \mathrm{H}$-progesterone to androgens by the rat testis during the second half of fetal life. Endocrinology, 78, 245.

Pearse, A. G. E. (1961) Histochemistry: theoretical and applied. Churchill, London.

Reynolds, E. S. (1963) The use of lead citrate at high $\mathrm{pH}$ as an electron opaque stain in electronmicroscopy. F. Cell Biol. 17, 208.

Richardson, K. C. (1962) The fine structure of autonomic nerve endings in smooth muscle of the rat vas deferens. F. Anat. 96, 427.

Roosen-Runge, E. C. \& Anderson, D. (1959) The development of the interstitial cells in the testis of the albino rat. Acta anat. 37, 125.

Schwarz, W. \& Merker, H. J. (1965) Die Hodenzwichenzellen der Ratte nach Hypophysektomie und nach Behandlung mit Chorion Gonadotropin und Amphenon B. Z. Zellforsch. mikrosk. Anat. 65, 272.

Steingerger, E. \& Ficher, M. (1968) Conversion of progesterone to testosterone by testicular tissue at different stages of maturation. Steroids, 11,351 .

Taladay, P. (1957) Enzymic mechanisms in steroid metabolism. Physiol. Rev. 37, 362.

Toren, D., Menon, K. M. J., Forchielli, F. \& Dorfman, R. I. (1964) In vitro enzymatic cleavage of the cholesterol side-chain in rat testis preparations. Steroids, 3, 381 .

WATson, M. L. (1958) Staining of tissue sections for electron microscopy with heavy metals. F. biophys. biochem. Cytol. 4, 475.

WATtenberg, L. W. (1958) Microscopical histochemical demonstration of steroid 3-beta-ol dehydrogenase in tissue sections. F. Histochem. Cytochem. 6, 225.

Woons, J. E. \& Dомм, L. V. (1966) A histochemical identification of the androgen-producing cells in the gonads of the domestic fowl and albino rat. Gen. comp. Endocr. 7, 559. 